\title{
Perancangan dan Analisa Kinerja Fiber to the Building (FTTB) untuk Mendukung Smart Building di Daerah Urban
}

\author{
Trivia Anggita ${ }^{1)}$, Liani Budi Rahman ${ }^{2)}$, Anshari Akbar ${ }^{3)}$, Muh Asnoer Laagu ${ }^{4)}$, dan Catur Apriono ${ }^{5 *}$ \\ 1,2,3,4,5) Departemen Teknik Elektro, Fakultas Teknik, Universitas Indonesia \\ Coresponding Email: ${ }^{*}$ catur@eng.ui.ac.id
}

\begin{abstract}
The development of digital technology makes it easy for humans to do activities, including compliance with the requirement of voice, data, and video communication in office buildings. Infrastructures are a primary consideration for a reliable connection, large-capacity, and stable communication lines. Recently, Fiber-optic communication systems are now the backbone of information signal delivery technology. This paper proposes a design of optical fiber transmission media for deployment in urban office buildings. It has been called fiber to the building (FTTB), which uses a fiber optic communication system to support the availability of multimedia network in an office area. A typical office building in an urban area has a multilevel structure that is used by various companies with multimedia network access services to support business activities. This study considers XGPON technology as a fiber optic-based broadband access technology that is deemed appropriate to the needs of the use of a multimedia network. The design begins with conducting a data collection survey. The next is the chosen device components based on the estimated distribution of the number of users. There are three parameters will be calculated include Power Link Budget (PLB), Rise Time Budget (RTB), and Bit Error Rate (BER), to determine the design feasibility. Based on PLB, RTB, and BER data, the proposed fiber to the building (FTTB) can meet the parameters to be achieved in the design, namely PLB of $-27,24 \mathrm{dBm}$ for downstream and $-11,68 \mathrm{dBm}$ for upstream, the value of is $0,049 \mathrm{~ns}$, and value of BER is 0,186 $x 10^{-1085}$. The design of FTTB can meet the requirement of users with a bandwidth of 9014,4 Mbps for 1200 users.
\end{abstract}

Key words : FTTB, Power Link Budget, Rise time budget, Bit Error rate.

\section{Pendahuluan}

Penggunaan layanan jasa multimedia seperti internet data, video, game online, video conference, video streaming, dan penggunaan cloud computing telah menjadi suatu kebutuhan bagi masyarakat. Semakin banyak permintaan terhadap kebutuhan akses jaringan yang cepat dengan biaya yang relatif murah dan mudah dalam pemasangan memicu terjadinya peningkatan perkembangan teknologi komunikasi dan informasi [1].

Tuntutan terhadap akses jaringan multimedia yang handal dan dengan kapasitas yang cukup besar sangat dirasakan penting terutama untuk pengguna di area perkantoran. Akses jaringan multimedia menjadi faktor penting untuk mendukung produktifitas kinerja karyawan dalam menjalankan bisnis perusahaan. Berbagai pilihan perangkat dan media akses jaringan yang digunakan belum memiliki kehandalan dalam memenuhi layanan yang ingin dicapai [2]. Media transmisi serat optik menawarkan kapasitas jaringan yang besar dengan kecepatan yang tinggi dan juga instalasi yang mudah khususnya di perkantoran pada area urban yang memiliki tingkat kepadatan pengguna yang cukup tinggi. Area perkantoran saat ini telah mengadopsi konsep smart building. Konsep smart building sudah banyak diterapkan pada beberapa gedung perkantoran di Jakarta dimana menggunakan otomatisasi untuk mengendalikan berbagai perangkat yang ada dalam gedung tersebut, seperti sistem keamanan gedung [3]. Smart building banyak menggunkan teknologi sensor dalam pengumpulan data. Sistem yang digunakan pada smart building tentunya membutuhkan konektifitas jaringan yang stabil dan cepat untuk mendukung kestabilan operasi [4].

Beberapa penelitian telah dilakukan tentang penggunaan teknologi FTTB (fiber to the building). Salah satunya adalah studi tentang pembangunan FTTB untuk layanan Ethernet dan model dari sisi pembangunan bagian teknologi dan ekonomi [5]. Penggunaan arsitektur FTTB juga diulas dengan menggabungkan arsitektur FTTB dan LAN (Local Area Network). Penelitian tersebut menyajikan penjelasan tentang bagaimana pembangunan arsitektur FTTB+LAN untuk mendapatkan akses jaringan kecepatan tinggi dengan biaya yang efektif dan fleksibel [6]. Pada penelitian lain membahas tentang perancangan FTTB di area perkantoran dengan menggunakan kabel serat optik jenis single-mode [7].

Paper ini menyajikan perancangan media transmisi serat optik FTTB atau fiber to the building dan analisa kinerja pada perkantoran di daerah perkotaan atau area urban dengan menggunakan teknologi 10 Gigabyte Passive Optical Network (XGPON). Teknologi XGPON memiliki karakteristik kapasitas yang lebih besar dibandingkan dengan teknologi yang digunakan pada penelitian sebelumnya [7][8]. Pemilihan gedung, parameter kelayakan dan biaya yang dibutuhkan menjadi hal yang perlu dipertimbangkan sebelum melakukan penggelaran jaringan serat optik. Selain dari itu, jumlah pengguna dan kebutuhan bandwidth juga perlu diperhitungkan pada saat perancangan akses jaringan.

Pada paper ini meninjau perencanaan penggelaran jaringan serat optik di Gedung Tifa, Kota Jakarta dengan karakteristik gedung perkantoran yang terletak di area urban seperti yang dapat dilihat pada Gambar 1. Gedung ini merupakan salah satu gedung yang digunakan oleh 
berbagai perusahaan yang membutuhkan layanan akses jaringan multimedia sebagai pendukung aktivitas bisnis dimana saat ini belum menggunakan media transmisi serat optik.

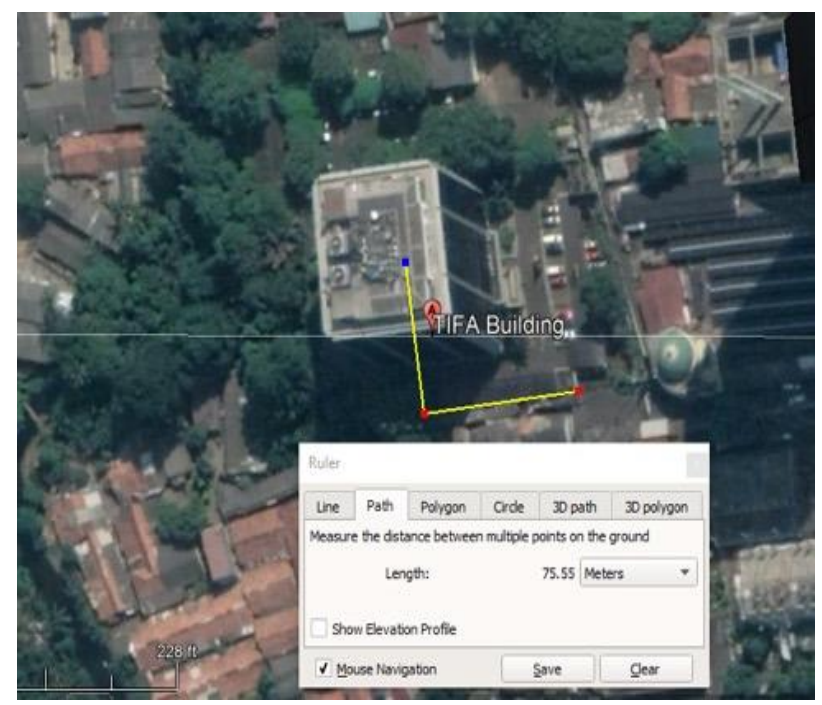

Gambar 1. Lokasi Gedung Tifa, Jakarta Selatan (online : https://www.sewakantorcbd.com)

Struktur dari paper disajikan dalam lima bagian. Bagian pertama membahas latar belakang penelitian. Pada bagian kedua akan menjelaskan tentang arsitektur dan teknologi yang akan digunakan pada perancangan. Diagram alur perancangan dan penghitungan kelayakan sistem akan dibahas pada bagian ketiga. Sedangkan bagian keempat akan membahas analisa dan hasil dari perhitungan yang telah dilakukan. Kesimpulan dan penutup akan disajikan di bagian kelima pada paper ini.

\section{Metodologi}

\section{A. Arsitektur FTTB}

Bagian kedua ini menyajikan ulasan tentang arsitektur yang akan digunakan untuk perancangan jaringan serat optik. Arsitektur yang digunakan disebut dengan FTTB atau fiber to the building dengan menggunakan teknologi akses jaringan yang disebut dengan teknologi XGPON (10 Gigabyte Passive Optical Network) untuk menyediakan kebutuhan bandwidth yang akan dicapai [3]. Berikut ini akan dijelaskan tentang defenisi dari kedua teknologi yang digunakan tersebut.

\section{Fiber to the Building}

FTTB atau bisa disebut juga sebagai teknologi fiber to the basement atau fiber to the building merupakan istilah umum untuk arsitektur jaringan dasar koneksi data yang dirancang atau ditempatkan pada gedung bertingkat dengan tujuan untuk mendapatkan bandwidth yang sesuai dengan kebutuhan. Arsitektur jaringan ini menggunakan serat optik sebagai media transmisi untuk jaringan lokal akses fiber.

Selain dari FTTB, teknologi lainnya dikenal dengan sebutan FTTH (fiber to the home) yang dirancang pada perumahan berbasis digital atau serat optik dan juga FTTC (fiber to the curb) dimana serat optik yang digunakan sebagai media transmisi dipasangkan pada tiang tinggi. Perancangan FTTB ini diharapkan mampu memenuhi kebutuhan pelanggan dengan menghemat sumber daya dan juga faktor kemudahan dalam pemasangan atau instalasi jaringan.

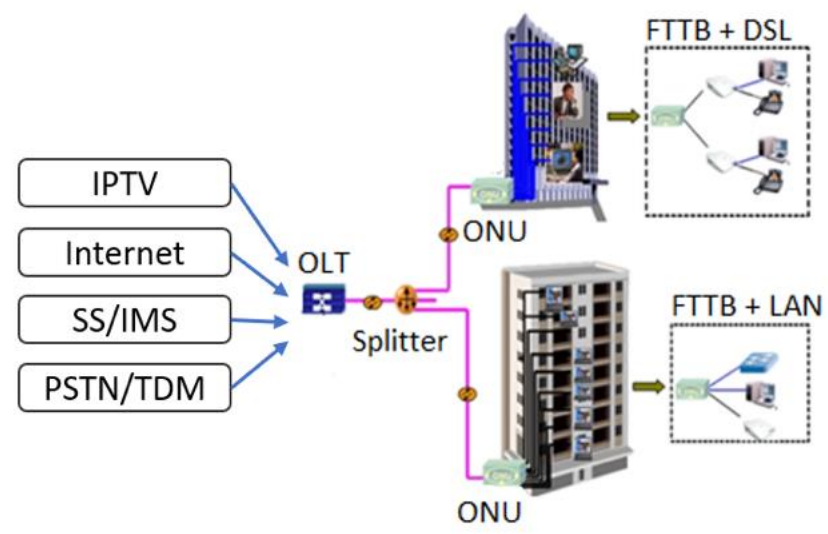

Gambar 2. Arsitektur Teknologi FTTB (online : http://wwwen.zte.com.cn)

Gambar 2 memperlihatkan arsitektur dari teknologi FTTB yang biasa digunakan. Terdapat dua jenis teknologi FTTB, yaitu FTTB yang dipasangkan dengan LAN dan FTTB yang dipasangkan dengan DSL (Digital Subscriber Line). Arsitektur jaringan FTTB+DSL biasanya digunakan untuk perkantoran yang hanya memerlukan jaringan untuk aplikasi suara maupun fax sehingga tidak memperhitungkan pembagian kapasitas untuk penggunaan aplikasi data internet. Sedangkan untuk FTTB+LAN biasa digunakan pada perkantoran yang membutuhkan jaringan untuk aplikasi multimedia. Dapat dilihat dari gambar tersebut bahwa alur kerja dari arsitektur ini bermula dari OLT (Optical Line Termination) untuk pengubahan sinyal listrik menjadi sinyal optik, sedangkan untuk pembagian jaringan ke arah pengguna menggunakan ONT (Optical Network Terminal).

\section{Teknologi XGPON}

Teknologi akses yang diperhitungkan pada penelitian ini adalah teknologi XGPON. Teknologi XGPON merupakan teknologi broadband akses berbasis serat optik. Teknologi ini melakukan distribusi traffic secara pasif atau dengan kata lain pada teknologi ini tetap menggunakan perangkat lain sebagai penyalur data ke pelanggan yang dituju, sedangkan serat optik hanya digunakan sebagai media transmisi. Teknologi yang dikembangkan oleh ITU-T G.987.x ini memiliki beberapa keunggulan dibandingkan dengan teknologi lainnya [4].

Keunggulan tersebut adalah nilai tingkat penetrasi yang relatif lebih baik dibandingkan dengan teknologi lainnya seperti GEPON [7][9]. Selain itu, bandwidth yang ditawarkan pada penggunaan teknologi ini bisa mencapai 10 Gbps untuk downstream dan bandwidth sebesar 2,5 Gbps untuk upstream. Dengan mempertimbangkan 
beberapa keunggulan tersebut, maka pada paper ini memperhitungkan penggunaan teknologi XGPON pada perancangan FTTB di gedung perkantoran area urban.

\section{B. Perancangan}

Gambar 3 menunjukkan diagram alur perancangan FTTB yang terdiri dari empat tahapan. Langkah pertama adalah melakukan pemilihan lokasi atau gedung yang akan dipasangkan jaringan serat optik seperti yang diperlihatkan pada Gambar 1. Setelah mengetahui lokasi dan keadaan dari gedung, tahap kedua adalah pemilihan perangkat yang disesuaikan dengan desain dari penggelaran jaringan. Penentuan kelayakan sistem dilakukan pada tahap ketiga bertujuan untuk memastikan bahwa perancangan yang dilakukan telah sesuai dengan standar. Ketika telah dipastikan bahwa sistem yang dibangun sudah masuk dalam parameter kelayakan sistem, maka tahap berikutnya adalah penggelaran distribusi jaringan.

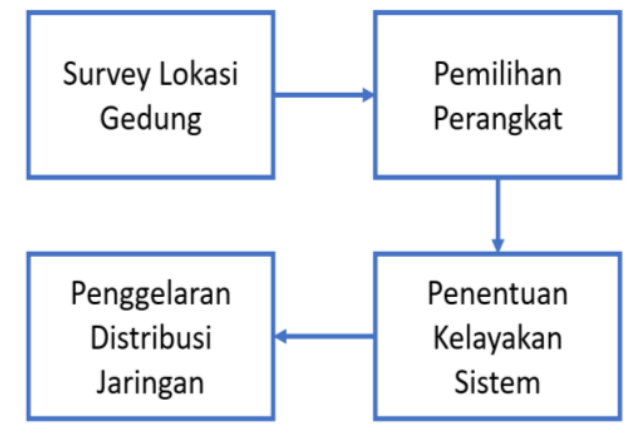

Gambar 3. Diagram alur perancangan FTTB

\section{Penentuan lokasi}

Alur proses perancangan FTTB yang dilakukan pertama kali adalah menentukan lokasi gedung. Dalam penelitian ini, Gedung Tifa akan menjadi obyek perancangan jaringan serat optik. Gambar 4 menunjukkan denah lantai gedung Tifa dan perencanaan tata letak serta jalur kabel serat optik.

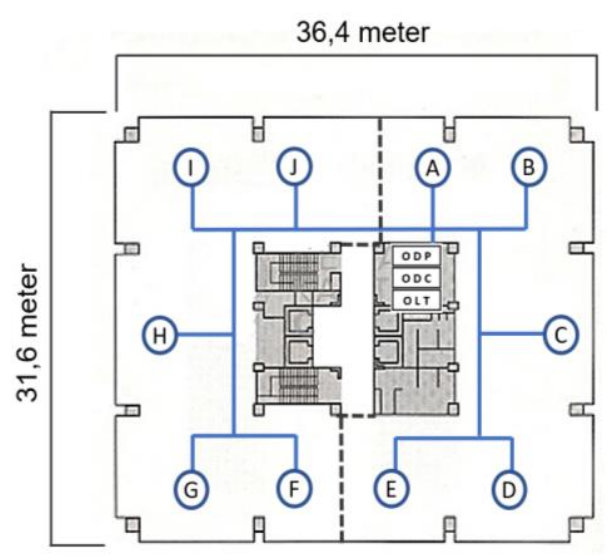

Gambar 4. Desain tata letak perangkat dan jalur kabel
Gambar 4 menunjukkan lokasi dengan kode untuk setiap ruang (space) yang akan dipasangkan perangkat jaringan. Gambar tersebut berlaku untuk setiap lantai, keterangan kode gambar A hingga J akan didiskusikan masing-masing pada penjelasan Tabel 2. Kondisi gedung menjadi dasar desain pendistribusian kabel optik. Pada area ruang kantor, kode space yang ditampilkan dalam huruf abjad menunjukkan pendistribusian ONT (Optical Network Terminal). Jumlah ONT pada masing-masing kode space berbeda, sesuai dengan kapasitas ruangan. Jumlah ONT yang dibutuhkan pada setiap lantai adalah 50 buah. Pada ruang perangkat, terdapat 1 buah OLT (Optical Line Terminal), 1 buah ODC (Optical Distribution Cabinet), dan 1 buah ODP (Optical Distribution Panel).

Perangkat OLT dan ODC hanya ada di lantai 1. ODP terletak di lantai 2 hingga lantai 12. Hal ini dikarenakan dalam perancangan membutuhkan OLT dan ODC masing-masing 1 buah. Kebutuhan panjang kabel dari OLT (Optical Line Termination) ke ONT dan jumlah ONT dan ODP menyesuaikan dengan kebutuhan pelanggan/user di setiap lantai. Jumlah OLT yang digunakan sebanyak satu buah dan jumlah ODC juga sebanyak satu buah. Kapasitas satu perangkat OLT mencapai 800 Gbps. ODC memiliki kapasitas 960 konektor. Kapasitas masing-masing perangkat ini sudah mencapai kebutuhan bandwidth yang diinginkan. Blok diagram rancangan penggelaran jaringan serat optik secara umum ditunjukkan pada Gambar 5.

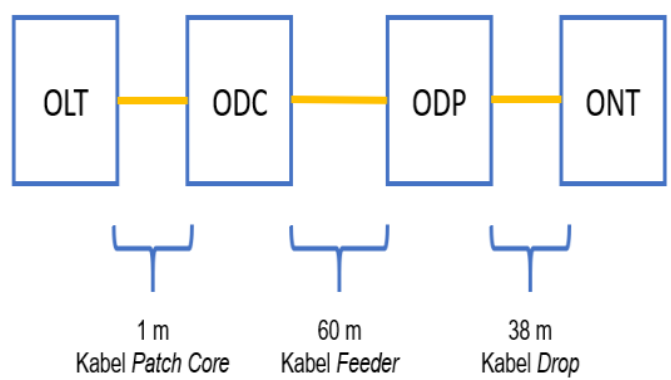

Gambar 5. Diagram rancangan penggelaran optik

Penempatan perangkat harus menyesuaikan kondisi gedung agar efisien dalam pendistribusian jaringan [8]. OLT dan ODC dapat ditempatkan pada basement gedung. ODP dapat ditempatkan pada ruang panel yang berada di setiap lantai. Sedangkan ONT ditempatkan di setiap lantai berdasarkan distribusi seperti pada Gambar 3. Pada Gambar 5 diperlihatkan panjang jarak antara masingmasing perangkat yang digunakan. Jenis kabel yang digunakan untuk menghubungkan OLT dan ODC menggunakan kabel patch core. Kabel feeder digunakan untuk menghubungkan ODC dan ODP. Kabel drop digunakan untuk menghubungkan ODP dan ONT.

Berdasarkan pada pertimbangan kapasitas Gedung, maka diperkirakan pengguna akan dapat mencapai 1200 pengguna. Perkiraan kebutuhan bandwidth untuk 1200 user ditampilkan pada Tabel 1 mencakup layanan suara (voice), video, dan data. Jumlah user di setiap lantai maksimum mencapai 100 user sehingga distribusi ONT sebanyak 10 buah dan satu ODP di setiap lantai [10]. 
Distribusi jumlah user di setiap ONT dan panjang kabel yang dibutuhkan untuk setiap ONT ditampilkan pada Tabel 2. Jumlah panjang kabel yang diperlukan dari ODP ke ONT di setiap lantai sepanjang 1195 meter. Sehingga total kebutuhan panjang kabel ODP ke ONT untuk 12 lantai adalah 14,340 meter. Jalur terjauh transmisi data dari OLT sampai ke ONT adalah sepanjang 99 meter ditambah $10 \%$ panjang kabel sehingga diperoleh jarak 108,9 meter.

Tabel 1. Alokasi kebutuhan bandwidth di Gedung Tifa

\begin{tabular}{cccc}
$\begin{array}{c}\text { Jenis } \\
\text { Layanan }\end{array}$ & $\begin{array}{c}\text { Jumlah } \\
\text { User }\end{array}$ & Bandwidth & $\begin{array}{c}\text { Jumlah } \\
\text { Bandwidth }\end{array}$ \\
\hline Voice & 1200 & $1 \mathrm{Mbps}$ & $1200 \mathrm{Mbps}$ \\
\hline Video & 1200 & $6 \mathrm{Mbps}$ & $7200 \mathrm{Mbps}$ \\
\hline Data & 1200 & $0,512 \mathrm{Mbps}$ & $614,4 \mathrm{Mbps}$ \\
\hline \multicolumn{5}{c}{ Total } & $9014,4 \mathrm{Mbps}$ \\
\hline
\end{tabular}

Tabel 2. Distribusi jumlah user tiap ONT dan kebutuhan panjang kabel dari ODP ke ONT

\begin{tabular}{|c|c|c|c|c|}
\hline $\begin{array}{l}\text { Kode } \\
\text { Space } \\
\end{array}$ & $\begin{array}{c}\text { Jumlah } \\
\text { User }\end{array}$ & $\begin{array}{l}\text { Jumlah } \\
\text { ONT }\end{array}$ & $\begin{array}{c}\text { Panjang } \\
\text { Kabel (m) }\end{array}$ & $\begin{array}{c}\text { Total } \\
\text { Panjang (m) }\end{array}$ \\
\hline $\mathrm{A}$ & 4 & 2 & 7 & 14 \\
\hline $\mathrm{B}$ & 10 & 5 & 17 & 85 \\
\hline $\mathrm{C}$ & 20 & 10 & 19 & 190 \\
\hline $\mathrm{D}$ & 10 & 5 & 33 & 155 \\
\hline $\mathrm{E}$ & 6 & 3 & 33 & 99 \\
\hline $\mathrm{F}$ & 4 & 2 & 38 & 76 \\
\hline G & 10 & 5 & 38 & 190 \\
\hline $\mathrm{H}$ & 20 & 10 & 24 & 240 \\
\hline $\mathrm{I}$ & 10 & 5 & 22 & 110 \\
\hline $\mathrm{J}$ & 6 & 3 & 12 & 36 \\
\hline \multicolumn{4}{|c|}{ Total per lantai } & $1195 \mathrm{~m}$ \\
\hline \multicolumn{4}{|c|}{ Jumlah lantai } & 12 lantai \\
\hline \multicolumn{4}{|c|}{ Grand Total } & $14340 \mathrm{~m}$ \\
\hline
\end{tabular}

\section{Perangkat yang digunakan}

Pemilihan perangkat yang digunakan juga harus memperhatikan kondisi gedung dan potensi perubahan kebutuhan di masa depan. Perangkat yang digunakan dalam perancangan FTTB pada Gedung Tifa ditampilkan pada Tabel 3. Kolom jumlah merupakan kebutuhan yang sesuai dengan desain perancangan sedangkan jumlah akhir merupakan kebutuhan perangkat yang didapatkan dari desain awal dengan ditambahkan 10\% sebagai cadangan ketika terjadinya kemungkinan buruk di luar perencanaan yang dilakukan. Penambahan ini dilakukan untuk perangkat dengan kemungkinan terjadinya kerusakan yang cukup besar, sehingga tidak semua perangkat perlu penambahan cadangan sebesar $10 \%$. Beberapa perangkat yang rentan terhadap kerusakan diantaranya adalah kabel dan connector.
Tabel 3. Perangkat dalam perancangan jaringan FTTB

\begin{tabular}{ccc}
\hline Nama Perangkat & Jumlah & $\begin{array}{c}\text { Jumlah } \\
\text { Akhir }\end{array}$ \\
\hline $\begin{array}{c}\text { Panjang kabel patch cord } \\
\text { G.657 (OLT ke ODC) }\end{array}$ & $12 \mathrm{~m}$ & $13.2 \mathrm{~m}$ \\
\hline $\begin{array}{c}\text { Panjang Kabel Feeder G. } \\
\text { 652D (ODC ke ODP) }\end{array}$ & $390 \mathrm{~m}$ & $429 \mathrm{~m}$ \\
\hline Rak OLT 19 inci 5U & 1 buah & 1 buah \\
\hline Rak ODC 19 inci 42U & 1 buah & 1 buah \\
\hline ODP 1:64 & 12 buah & 12 buah \\
\hline Core serat optik & 12 core & 12 core \\
\hline $\begin{array}{c}\text { Panjang Kabel Drop G. } \\
\text { 652D (Splitter ke ONT) }\end{array}$ & $14340 \mathrm{~m}$ & $15774 \mathrm{~m}$ \\
\hline ONT ZTE 660 & 600 buah & 600 buah \\
\hline Connector SC APC & 1344 buah & 1477 buah \\
\hline $\begin{array}{c}\text { Passive Splitter 1:64 SC } \\
\text { APC }\end{array}$ & 12 buah & 12 buah \\
\hline SFP LX transmitter & 1 buah & 1 buah \\
\hline SFP LX receiver & 1 buah & 1 buah \\
\hline
\end{tabular}

\section{Pemilihan dan Spesifikasi Perangkat}

Pemilihan perangkat yang tepat merupakan salah satu parameter yang perlu diperhatikan dalam penggelaran jaringan serat optik. Pemilihan perangkat ditentukan dari kebutuhan pengguna dan manajemen biaya yang efisien saat proses penggelaran. Perangkat yang digunakan dalam penggelaran optik di Gedung Tifa adalah sebagai berikut ini:

$3.1 O L T$

OLT merupakan titik akhir dari layanan, yang berfungsi mengkonversi sinyal listrik (provider) dan sinyal optik yang diperhitungkan dalam jaringan yang akan dibangun [11]. OLT yang digunakan dalam perancangan ini adalah OLT ZTE ZXA10 C300 yang mampu menampung jumlah maksimum subscriber 16384 dengan kapasitas card sebanyak 14 service cards [12].

3.2 ODC

ODC merupakan tempat instalasi sambungan dari jaringan fiber single mode, biasanya dikenal sebagai ruang manajemen jaringan. ODC yang digunakan yakni ODC ORS 2/600 dari Micos Telecom [13]. ODC ini sangat cocok digunakan untuk instalasi dalam Gedung dengan maksimum 960 koneksi optik.

3.3 ODP

ODP merupakan perangkat yang berfungsi sebagai pelindung sambungan optik. ODP yang digunakan adalah dari Linkwell LW-ODB-24B ODP Box - 24 fibers, dengan kapasitas maksimum SC: 24 fibers dan LC: 48 fibers [14].

3.4 Splitter

Pada perancangan ini material splitter yang dipilih adalah splitter 1:64 yang berfungsi membagi cahaya dan mendistribusikannya ke saluran yang berbeda. Splitter yang digunakan adalah Splitter PLC FO SC APC:1:64. Splitter ini dapat mencukupi kebutuhan distribusi dari ODP ke ONT untuk satu lantai [15]. 


\subsection{ONT}

ONT merupakan terminal akhir dalam jaringan serat optik yang langsung terhubung ke pelanggan. ONT yang dibutuhkan mendukung jaringan LAN maupun telepon. ONT yang digunakan adalah ONT ZTE F660 yang memiliki sensitifitas $-28 \mathrm{dBm}$ [16].

3.6 Serat Optik

Jenis serat optik yang digunakan adalah single mode. Ada dua jenis serat optik yang digunakan yakni G.657 dan G.652D. Perbedaan terdapat pada karakteristik atenuasinya [17]. Serat optik G.657 digunakan untuk sambungan dari OLT ke ODC sebagai kabel patch cord, sedangkan serat optik G.652D digunakan sebagai kabel feeder ODC ke ODP dan sebagai splitter ke ONT.

3.7 SFP (Small Form Factor Pluggable )

SFP yang digunakan dalam perancangan ini adalah SFP-LX Single mode, yang mendukung proses penerimaan dan transmisi dengan kemampuan wavelength $1310 \mathrm{~nm}$ [18]. SFP-LX juga cocok dengan tipe kabel G.652.

\section{Kebutuhan Sumber Daya}

Penggelaran jaringan serat optik membutuhkan penghitungan manajemen biaya perangkat dan sumber daya yang digunakan. Biaya perangkat merujuk pada kebutuhan pengguna pada gedung Tifa. Sedangkan untuk manajemen biaya untuk kebutuhan sumber daya merujuk pada kebutuhan pekerjaan instalasi. Estimasi biaya yang dibutuhkan dalam perancangan ini ditampilkan pada Tabel 4. Kebutuhan perangkat yang akan digunakan menyesuaikan dengan kebutuhan utama penggelaran dalam gedung. OLT yang dibutuhkan adalah 1 buah sebagai sentral yang menghubungkan jaringan luar Gedung ke jaringan dalam Gedung.

Sebuah perangkat ODC akan menghubungkan jaringan dari OLT ke masing-masing lantai. Kebutuhan ONT sebanyak 600 buah dengan masing-masing lantai akan menggunakan 50 buah ONT. Pada Gambar 4 menunjukkan jumlah perangkat yang dibutuhkan dengan menyesuaikan denah Gedung pada tiap lantai. Setiap lantai dilengkapi splitter 1:64 yang dipasang di dalam kotak ODP. Kebutuhan kabel patch cord sepanjang 12 meter, kabel feeder sepanjang 390 meter dan kabel drop sepanjang 15.774 meter. Masing-masing kabel memiliki karakteristik dan harga yang berbeda-beda.

Selain dari total penghitungan biaya untuk kebutuhan perangkat yang akan digunakan, biaya jasa penggelaran juga perlu untuk diperhitungkan [19]. Estimasi biaya jasa dan total biaya penggelaran serat optik di Gedung Tifa ditampilkan pada Tabel 5. Estimasi tersebut merujuk pada peraturan Menteri Komunikasi dan Informatika tahun 2007 mengenai ketentuan jasa sewa jaringan. Kebutuhan jasa dalam penggelaran optik di Gedung Tifa yakni instalasi kabel patch cord, feeder dan drop. Selain jasa instalasi, terdapat juga jasa splicing, jasa tes OTDR (Optical Time-domain Reflectometer) dan OPM (Optical Power Meter). Total biaya kebutuhan dalam proses penggelaran optik di Gedung Tifa adalah penjumlahan dari biaya kebutuhan perangkat dan biaya jasa instalasi ditambah dengan biaya tak terduga dalam proyek dan pajak pertambahan nilai sebesar $10 \%$.

Tabel 4. Estimasi Kebutuhan biaya perangkat

\begin{tabular}{ccc}
\hline Nama Perangkat & Jumlah & Harga (Rp) \\
\hline OLT ZTE ZXA10 C300 & 1 buah & 34.860 .000 \\
\hline ONT F660 ZTE & 600 buah & 9.000 .000 \\
\hline $\begin{array}{c}\text { Splitter PLC Serat Optik } \\
\text { SC APC 1:64 }\end{array}$ & 12 buah & 11.832 .000 \\
\hline ORS 2/600 ODC & 1 buah & 11.700 .000 \\
\hline LW-ODB-24B ODP Box & 12 buah & 9.000 .000 \\
\hline $\begin{array}{c}\text { Kabel } \text { Patch Cord G.657 } \\
\text { (OLT ke ODC) }\end{array}$ & $12 \mathrm{~m}$ & 300.000 \\
\hline $\begin{array}{c}\text { Kabel Feeder G.652D } \\
\text { (ODC ke ODP) }\end{array}$ & $390 \mathrm{~m}$ & 7.800 .000 \\
\hline $\begin{array}{c}\text { Kabel Drop G.652D } \\
\text { (Splitter ke ONT) }\end{array}$ & $15774 \mathrm{~m}$ & 315.480 .000 \\
\hline Connector SC APC & 1477 buah & 11.077 .500 \\
\hline SFP LX-transmitter & 1 buah & 1.500 .000 \\
\hline SFP LX-receiver & 1 buah & 1.500 .000 \\
\hline Total & Rp.442.549.500 \\
\hline
\end{tabular}

Tabel 5. Estimasi Biaya jasa penggelaran

\begin{tabular}{lcr}
\hline \multicolumn{1}{c}{ Nama Perangkat } & Jumlah (Rp) & Harga (Rp) \\
\hline $\begin{array}{l}\text { Instalasi kabel } \text { patch } \text { cord } \\
\text { G.657 }\end{array}$ & $80.000 / \mathrm{m}$ & 960.000 \\
\hline $\begin{array}{l}\text { Instalasi kabel } \text { feeder } \\
\text { G.652D }\end{array}$ & $25.000 / \mathrm{m}$ & 9.750 .000 \\
\hline Instalasi kabel drop G.652D & $25.000 / \mathrm{m}$ & 393.600 .000 \\
\hline Jasa Splicing FO & $350.000 /$ core & 4.200 .000 \\
\hline Jasa Tes OTDR dan OPM & $350.000 /$ core & 4.200 .000 \\
\hline Instalasi serat optik 12 core & $65.000 /$ core & 780.000 \\
\hline Biaya Kebutuhan Perangkat & & 442.549 .500 \\
\hline Biaya Jasa Instalasi & & 413.490 .000 \\
\hline PPN (10\%) & 85.603 .950 \\
\hline Biaya Tak Terduga (10\%) & & 85.603 .950 \\
\hline \multicolumn{2}{c}{ Total Biaya } & Rp. 1.027 .247 .400 \\
\hline
\end{tabular}

\section{Kelayakan sistem}

Pada bagian ini akan menjelaskan tentang parameter kelayakan sistem dari perancangan jaringan yang diusulkan. Terdapat tiga parameter kelayakan sistem yang diperhitungkan, yaitu Power Link Budget, Rise Time Budget dan Bit Error Rate.

\subsection{PLB (Power Link Budget)}

Power Link Budget diartikan sebagai alokasi daya yang melewati serat optik setelah mengalami loss atau rugi-rugi seperti rugi-rugi redaman serat optik, loss atau rugi-rugi sambungan dan konektor hingga sampai pada sisi penerima. Power budget diukur dengan satuan decibell (dB). Penghitungan power link budget dibagi menjadi dua yaitu penghitungan pada sisi downstream dan sisi upstream

\section{A. Power Link Budget Downstream}

Pada sisi downstream, perhitungan ditinjau dari OLT ke ONT user. Nilai daya terima ONT dapat diperoleh dengan menghitung nilai redaman total terlebih dahulu. Perhitungan daya terima menggunakan data dengan penambahan panjang kabel cadangan sebesar $10 \%$. Data yang diperlukan untuk menghitung nilai PLB downstream ditunjukkan pada Tabel 6 . 
Daya maksimum yang pancarkan oleh OLT sebesar 3 $\mathrm{dBm}$ dengan sensitifitas detektor pada OLT dan ONT adalah $-28 \mathrm{dBm}$ sampai $-8 \mathrm{dBm}$. Dalam proses transmisi terjadi redaman pada kabel serat optik sebesar 0,4 dB/km. Redaman juga terjadi akibat sambungan/splice sebesar $0,1 \mathrm{~dB}$ tiap splice dari 8 sambungan yang dilakukan. Redaman lain terjadi pada konektor, dan splitter masing masing 0,3 dB dan $21 \mathrm{~dB}$.

Tabel 6. Data perhitungan downstream

\begin{tabular}{ccc}
\hline No & Parameter & Nilai \\
\hline 1 & $\begin{array}{c}\text { Daya keluaran sumber optik } \\
(\text { OLT) }\end{array}$ & $3 \mathrm{dBm}$ \\
\hline 2 & $\begin{array}{c}\text { Sensitivitas detektor } \\
(\text { OLT/ONT) }\end{array}$ & $\begin{array}{c}-28 ;-8 \\
\mathrm{dBm}\end{array}$ \\
\hline 3 & $\begin{array}{c}\text { Redaman Serat optik } \\
\text { G.652D (1310 nm) }\end{array}$ & $0.4 \mathrm{~dB} / \mathrm{Km}$ \\
\hline 4 & $\begin{array}{c}\text { Redaman Serat optik G.657 } \\
(1310 \text { nm) }\end{array}$ & $0,4 \mathrm{~dB} / \mathrm{Km}$ \\
\hline 5 & Redaman Fusion Splice & $\begin{array}{c}0,1 \\
\mathrm{~dB} / \text { splice }\end{array}$ \\
\hline 6 & Konektor & $0,3 \mathrm{~dB}$ \\
\hline 7 & Splitter 1:64 & $21 \mathrm{~dB}$ \\
\hline 8 & Jumlah Sambungan & 8 buah \\
\hline 9 & Jumlah Konektor & 8 buah \\
\hline 10 & $\begin{array}{c}\text { Panjang Kabel }(0.099 \mathrm{Km}+ \\
(10 \% \text { x 0.099 Km) }\end{array}$ & $0,1089 \mathrm{Km}$ \\
\hline
\end{tabular}

Persamaan 1 digunakan untuk mendapatkan nilai redaman total. $\alpha_{\text {tot }}$ adalah redaman total dalam $(\mathrm{dB})$. L adalah panjang serat optik $(\mathrm{Km}) . \alpha_{\text {serat }}, \alpha_{\text {konektor }}, \alpha_{\text {splice }}, \alpha_{\text {splitter }}$ masing-masing adalah redaman pada serat optik $(\mathrm{dB})$, redaman konektor $(\mathrm{dB})$, redaman splice $(\mathrm{dB})$, dan redaman splitter (dB). $N_{\text {konektor }}$ dan $N_{\text {splice }}$ masing-masing adalah jumlah konektor dan sambungan. [20]

$$
\begin{gathered}
\alpha_{\text {tot }}=\text { L. } \alpha_{\text {serat }}+N_{\text {konektor }} \cdot \alpha_{\text {konektor }}+ \\
N_{\text {splice }} \cdot \alpha_{\text {splice }}+\alpha_{\text {splitter }}
\end{gathered}
$$

Sedangkan daya yang diterima ONT diberikan pada Persamaan 2. $P_{r x}$ adalah daya yang diterima $(\mathrm{dBm}) . P_{t x}$ daya yang ditransmisikan oleh transmitter $(\mathrm{dBm})$. $\alpha_{\text {tot }}$ adalah redaman total $(\mathrm{dB})$ yang terjadi. SM adalah system margin $(\mathrm{dB})$ yang digunakan. [21]

$$
P_{r x}=P_{t x}-\alpha_{t o t}-S M
$$

\section{B. Power Link Budget Upstream}

Pada sisi upstream, perhitungan ditinjau dari ONT user ke OLT. Nilai daya terima pada OLT dapat diketahui juga dengan menghitung nilai redaman total. Di sisi upstream nilai redaman yang diperhitungkan adalah redaman pada splitter. Keluaran splitter di sisi upstream tidak menjadi 1:64 tetapi 1:1. Sehingga, nilai redaman splitter diganti dengan nilai sambungan. Pada penghitungan power link budget upstream digunakan nilai redaman sebesar $2,94 \mathrm{~dB}$.
Tabel 7. Data perhitungan upstream

\begin{tabular}{ccc}
\hline No & Parameter & Nilai \\
\hline 1 & Daya keluaran ONT $\left(\mathrm{P}_{\mathrm{tx}}\right)$ & $0.5 \mathrm{dBm}$ \\
\hline 2 & $\begin{array}{c}\text { Sensitivitas detektor } \\
\text { (OLT/ONT) }\end{array}$ & $-28 ;-8 \mathrm{dBm}$ \\
\hline 3 & $\begin{array}{c}\text { Redaman Serat optik G.652D } \\
(1310 \mathrm{~nm})\end{array}$ & $0,4 \mathrm{~dB} / \mathrm{Km}$ \\
\hline 4 & $\begin{array}{c}\text { Redaman Serat optik G.657 } \\
(1310 \mathrm{~nm})\end{array}$ & $0,4 \mathrm{~dB} / \mathrm{Km}$ \\
\hline 5 & Redaman Fusion Splice & $\begin{array}{c}0,1 \\
\mathrm{~dB} / \mathrm{splice}\end{array}$ \\
\hline 6 & Konektor & $0,3 \mathrm{~dB}$ \\
\hline 7 & Splitter $1: 64$ & $2,938 \mathrm{~dB}$ \\
\hline 8 & Jumlah Sambungan & $8 \mathrm{buah}$ \\
\hline 9 & Jumlah Konektor & $8 \mathrm{buah}$ \\
\hline 10 & $\begin{array}{c}\text { Panjang Kabel }(0.099 \mathrm{Km}+ \\
(10 \% \text { x 0.099 Km) }\end{array}$ & $0,1089 \mathrm{Km}$ \\
\hline
\end{tabular}

Tabel 7 merupakan data nilai yang digunakan untuk menghitung nilai power link budget di sisi upstream. Nilai system margin yang digunakan pada perhitungan adalah sebesar 6 dB. System margin tersebut ditentukan sebagai nilai yang diperuntukkan untuk mendapatkan penerimaan daya optik yang handal terhadap kemungkinan faktorfaktor yang tidak dipertimbangkan [22].

Untuk perhitungan upstream, daya keluaran ONT sebesar $0,5 \mathrm{dBm}$. Redaman yang terjadi pada splitter sebesar 2,94 dB lebih besar dari redaman splitter pada sisi downstream. Hal ini disebabkan karena keluaran splitter di sisi upstream tidak menjadi 1:64 tetapi 1:1. Parameter perhitungan lainnya seperti redaman serat optik, redaman splice, redaman pada konektor, panjang kabel, dan jumlah konektor dan sambungan adalah tidak berbeda dengan data downstream.

\subsection{RTB (Rise Time Budget)}

Merupakan parameter kelayakan lainnya yang digunakan untuk menentukan batasan dispersi dari jaringan serat optik. Pengkodean yang diperhitungkan adalah NRZ (Non-Return to Zero) dengan batas nilai sebesar $70 \%$ dari periode. Untuk menghitung Rise time budget menggunakan Persamaan 3 [7]. Tr merupakan batas maksimum rise time dalam ns dan $\mathrm{Br}$ adalah nilai bit rate dalam $\mathrm{Hz}$.

$$
\operatorname{Tr}=\frac{70 \%}{B r}
$$

Penghitungan rise time budget dilakukan di sisi downstream dan di sisi upstream. Perbedaan pada kedua sisi tersebut terletak pada nilai bit rate masing-masing. Pada sisi downstream nilai bit rate yang digunakan sebesar 10 Gbps sedangkan pada sisi upstream nilai yang digunakan adalah 2,5 Gbps.

Nilai rise time budget yang perlu diperhitungkan didapatkan dari Persamaan 4. $t_{t x}$ adalah rise time di sisi pengirim dan $t_{r x}$ rise time di sisi penerima. $t_{\text {intermodal }}$ adalah modal dispersion rise rime (bernilai nol untuk serat optik single mode). Sedangkan, $t_{\text {material }}$ adalah material dispersion rise time (ns). Material dispersion bisa 
diperoleh dengan menggunakan Persamaan 5. $\Delta \sigma$ adalah lebar spektral $(\mathrm{nm}) . L$ adalah panjang serat optik $(\mathrm{Km})$, dan $D_{m}$ adalah dispersi material (ps/nm.Km) [7].

$$
\begin{aligned}
& t_{\text {Sys }}=\left(t_{t x}^{2}+t_{\text {material }}^{2}+t_{\text {intermodal }}^{2}+t_{r x}\right)^{1 / 2}(4) \\
& t_{\text {material }}=\left(\begin{array}{llll}
\Delta \sigma & \times & < & D_{m}
\end{array}\right)
\end{aligned}
$$

Tabel 8. Data perhitungan rise time system

\begin{tabular}{ccc}
\hline No & Parameter & Nilai \\
\hline 1 & $\begin{array}{c}\text { Panjang serat optik } \\
\text { G.652D }(0,098 \mathrm{Km}+ \\
(10 \% \times 0,098 \mathrm{Km})\end{array}$ & $0,107 \mathrm{Km}$ \\
\hline \multirow{3}{*}{$\begin{array}{c}\text { Panjang serat optik } \\
\text { G.657 }(0,001 \mathrm{Km}+ \\
(10 \% \times 0,001 \mathrm{Km})\end{array}$} & $0,001 \mathrm{Km}$ \\
\hline 3 & Rise time transmitter & $0,035 \mathrm{~ns}$ \\
\hline 4 & Rise time receiver & $0,035 \mathrm{~ns}$ \\
\hline 5 & Lebar spektral & $1 \mathrm{~nm}$ \\
\hline 6 & Dispersi material G.657 & $\begin{array}{c}0,11 \\
\mathrm{ps} / \mathrm{nm} . \mathrm{Km}\end{array}$ \\
\hline 7 & Dispersi material & 0,092 \\
G.652D & $\mathrm{pm} . \mathrm{Km}$ \\
\hline
\end{tabular}

Tabel 8 merupakan data yang digunakan untuk mendapatkan nilai rise time system pada perancangan jaringan dan analisa kinerja. Nilai untuk data perhitungan rise time system pada Tabel 8 didapatkan dari spesifikasi alat yang digunakan. Untuk nilai rise time transmitter dan rise time receiver didapatkan dari spesifikasi perangkat OLT yang digunakan. Sedangkan untuk nilai panjang serat optik, lebar spektral serta nilai dispersi material didapatkan dari spesifikasi berdasarkan standar ITU G.657 dan G.652D.

\subsection{BER (Bit Error Rate)}

Kualitas transmisi data pada komunikasi serat optik dapat dinilai secara langsung dengan mengukur seberapa baik sinyal output terhadap sinyal input. Pengukuran bit error rate dilakukan dengan membandingkan sinyal input dan output digital untuk menilai jumlah bit error yang diterima dengan Persamaan 6 [22]. E(t) adalah jumlah bit error yang diterima dalam waktu $(t) . N(t)$ adalah jumlah bit yang dikirim dalam waktu $t$.

$$
B E R=\frac{E(t)}{N(t)}
$$

Nilai BER dapat pula diperoleh dengan Persamaan 7 dan 8. Po adalah daya sinar yang diterima photodetector $(\mathrm{W})$. $N$ adalah jumlah photon/pulse. $h$ adalah konstanta Planck $\left(6,626 \times 10^{-34} \mathrm{~J} . \mathrm{s}\right) . c$ adalah kecepatan cahaya $\left(3 \times 10^{8}\right.$ $\mathrm{m} / \mathrm{s}), \quad B$ adalah data rate (bps). $\lambda$ adalah panjang gelombang $(1310 \mathrm{~nm})$. $\operatorname{Pr}(0)$ adalah probabilitas error.

$$
\begin{aligned}
& P_{o}=N \frac{h c B}{2 \lambda} \\
& B E R=\operatorname{Pr}(0)=e^{-N}
\end{aligned}
$$

\section{Hasil Dan Pembahasan}

Bagian ini membahas hasil perhitungan serta analisa kinerja yang telah dilakukan. Berdasarkan hasil perhitungan dapat diketahui apakah sistem yang dirancang telah layak untuk memenuhi kebutuhan yang hendak dicapai atau tidak. Berikut adalah hasil dan analisa kelayakan sistem pada masing-masing parameter perancangan, yaitu Power Link Budget, Rise Time Budget, dan Bit Error Rate.

Parameter kelayakan sistem yang pertama adalah dengan menghitung nilai Power Link Budget. Nilai Power Link Budget yang dihitung dibagi menjadi dua, yaitu Power Link Budget downstream dan Power Link Budget upstream. Perbedaan antara kedua hal tersebut terletak pada nilai redaman splitter. Nilai redaman splitter untuk power link budget downstream didapatkan dari perhitungan sebesar 24,24 dB dan menghasilkan nilai Power Link Budget downstream sebesar -27,24 dBm dengan menggunakan system margin sebesar $6 \mathrm{~dB}$ dan daya transmitter sebesar $3 \mathrm{dBm}$. Power Link Budget downstream ini merupakan besar nilai daya yang terdeteksi di sisi ONT dalam satuan $\mathrm{dBm}$.

Sedangkan untuk Power Link Budget upstream adalah besar nilai daya yang terdeteksi di sisi OLT dalam satuan $\mathrm{dBm}$. Dari penghitungan yang telah dilakukan nilai Power Link Budget upstream dihasilkan sebesar -11,68 dBm. Hal ini terjadi karena nilai redaman splitter pada Power Link Budget upstream sebesar $6,18 \mathrm{~dB}$, sedangkan daya transmitter yang diterima oleh OLT sebesar 0,5 dBm. Berdasarkan hasil perhitungan Power Link Budget pada sisi downstream dan upstream, perancangan ini dapat memenuhi spesifikasi dari sensitivitas detektor baik pada OLT maupun ONT dengan nilai daya yang diterima antara $-28 \mathrm{dBm}$ hingga $-8 \mathrm{dBm}$. Berdasarkan pada hasil yang dicapai, maka Power Link Budget telah terpenuhi.

Parameter kedua yang diperhitungkan adalah nilai Rise Time Budget yang dihitung dibagi menjadi dua, yaitu Rise Time Budget Downstream dan Rise Time Budget Upstream. Kedua nilai yang dihasilkan memiliki perbedaan dari nilai bit rate yang digunakan. Pada perhitungan Rise Time Budget downstream didapatkan nilai sebesar $0,07 \mathrm{~ns}$ dengan menggunakan bit rate 10 Gbps, untuk perhitungan Rise Time Budget upstream didapatkan nilai sebesar $0,28 \mathrm{~ns}$ dengan menggunakan bit rate 2,5 Gbps. Dari hasil nilai Rise Time Budget downstream dan upstream ini didapatkan nilai Rise Time System yang menjadi parameter kelayakan sistem. Berdasarkan hasil perhitungan Rise Time System, nilai tersebut dapat memenuhi pada Rise Time Budget yang dibutuhkan, yaitu kurang dari 0,07 ns untuk sisi downstream dan 0,28 ns untuk sisi upstream. Nilai Rise Time System yang didapat sebesar 0,049 ns pada perancangan ini memenuhi parameter yang hendak dicapai.

Parameter ketiga yang diperhitungkan pada perancangan ini adalah nilai Bit Error Rate. Dari hasil perhitungan yang dilakukan didapatkan nilai Bit Error Rate pada perancangan ini sebesar $0,186 \times 10^{-1085}$ dengan menggunakan rumus (7) dan (8). Dengan nilai minimum yang harus dipenuhi pada komunikasi serat optik sebesar $10^{-9}$, maka untuk parameter Bit Error Rate pada 
perancangan ini memenuhi kelayakan sistem. Nilai dari Power Link Budget, Rise Time Budget, dan Bit Error Rate yang dilakukan pada penelitian ini sebatas pada perhitungan dengan menggunakan beberapa asumsi yang disesuaikan dengan parameter kelayakan suatu perangkat untuk tujuan penggunaan jaringan FTTB.

Potensi masalah yang dapat muncul dari perancangan ini juga disajikan dengan beberapa kemungkinan yang dirasa akan muncul. Kemungkinan terjadinya kekurangan dalam hal panjang kabel yang digunakan ketika terjadi renovasi gedung merupakan salah satu hal yang perlu diantisipasi. Penyelesaian yang dapat dilakukan adalah dengan menambahkan panjang kabel 5\% sampai dengan $10 \%$ dari kebutuhan perhitungan perancangan. Sama halnya ketika terjadi peningkatan kebutuhan pengguna (jumlah ONT) secara signifikan, maka perlu dilakukan penyediaan tambahan output splitter dari jumlah yang digunakan. Untuk mengantisipasi kekurangan jumlah konektor yang rusak saat pemasangan perlu dilakukan penambahan $10 \%$ jumlah konektor dari kebutuhan desain. Hal lain yang mungkin terjadi adalah kelebihan penggunaan kabel, dengan demikian perlu dilakukan evaluasi terhadap desain jalur kabel agar lebih efisien dalam pemasangan.

Beberapa dampak positif yang mungkin terjadi adalah mendukung kebutuhan bandwidth yang lebar sehingga kebutuhan multimedia dan telekomunikasi pada area perkantoran dapat terpenuhi. Penggunaan serat optik sebagai media akses jaringan dapat meningkatkan produktifitas karyawan perkantoran. Selain itu, penggunaan serat optik juga akan memungkinkan menurunkan rugi-rugi. Dari sisi proses instalasi cenderung lebih fleksibel untuk penggunaan serat optik karena nilai diameter dari kabel dan konektor yang lebih kecil dibandingkan dengan media lainnya. Dari sisi biaya perawatan, serat optik cenderung relatif lebih kecil karena penggunaan jaringan serat optik cenderung aman terhadap gangguan. Selain dari itu, penggunaan jaringan serat optik akan lebih menghemat biaya ketika diperlukan tambahan kapasitas penggunaan, karena tidak perlu melakukan penggelaran serat optik baru.

\section{KESIMPULAN}

Telah dilakukan model perencanaan dan juga analisa kinerja untuk penggelaran jaringan fiber to the building di daerah urban. Berdasarkan hasil perhitungan dan analisa terhadap perancangan yang dibuat, kesimpulan yang didapat diantaranya adalah besarnya daya terima $\left(\mathrm{P}_{\mathrm{rx}}\right)$ pada perhitungan Power Link Budget baik di sisi upstream maupun downstream memenuhi nilai minimum parameter yang hendak dicapai, yaitu -28 sampai $-8 \mathrm{dBm}$. Nilai $\mathrm{P}_{\mathrm{rx}}$ yang didapat adalah $-27,24 \mathrm{dBm}$ untuk downstream dan 11,68 dBm untuk upstream.

Nilai parameter Rise Time Budget saat uplink dan downlink yang didapat dari perancangan adalah sebesar $0,049 \mathrm{~ns}$. Nilai tersebut memenuhi parameter yang hendak dicapai yaitu 0,07 ns untuk upstream dan 0,28 ns untuk downstream. Nilai BER yang diperoleh memenuhi parameter yang hendak dicapai, yaitu kurang dari $10^{-9}$, dimana nilai yang didapatkan adalah $0,186 \times 10^{-1085}$.
Berdasarkan data hasil perhitungan PLB, RTB, dan BER, perancangan FTTB dapat memenuhi parameter yang hendak dicapai dalam perancangan, yaitu kebutuhan bandwidth sebesar 9014,4 Mbps untuk 1200 user. Penelitian ini diharapkan dapat menjadi bahan referensi yang dapat digunakan bagi penyedia jaringan serat optik di area perkantoran daerah urban.

\section{DAFTAR Pustaka}

[1] D. M. S. Reyga Prayoga, Akhmad Hambali, "Perancangan Jaringan Akses Fiber To the Home (Ftth) Menggunakan Teknologi 10-Gigabit-Capable Passive Optical Network (Xgpon) Untuk Komplek Pertamina," e-Proceeding Eng. Telkom Univ., vol. 5, no. 3, pp. 5367-5373, 2018.

[2] N. Dewi and M. Hamdani, "Perancangan Jaringan FTTB GPON Untuk Layanan Triple Play di Surya Cipta Industri," vol. 25, no. 1, pp. 17-24, 2015.

[3] S. Wibowo, A. W. Purwantiasning, and D. Hantono, "Penerapan Konsep Bangunan Pintar Pada Perencanaan Kantor Pusat Penelitian dan Pengembangan Teknologi 'APPLE' di Jakarta," Purwarupa, vol. 1, no. 1, pp. 7-16, 2017.

[4] A. H. Buckman, M. Mayfield, and S. B. M. Beck, "What is a smart building?," Smart Sustain. Built Environ., vol. 3, no. 2, pp. 92-109, 2014.

[5] S. Azodolmolky and I. Tomkos, "Techno-economic study of a modeled active Ethernet FTTB deployment," Proc. 6th Int. Symp. Commun. Syst. Networks Digit. Signal Process. CSNDSP 08, pp. 496-499, 2008.

[6] P. Parol and M. Pawłowski, "FTTB + LAN : a Flexible Access Architecture for Residential and Business Users 1," vol. 2012, no. 1, pp. 3-27, 2013.

[7] H. B. Sembiring, T. N. D. S. T, B. Uripno, and S. Stat, "PERANCANGAN JARINGAN FIBER TO THE BUILDING ( FTTB ) UNTUK SUPPORT SMART BUILDING MENGGUNAKAN GPON DI GRAHA POS INDONESIA , BANDUNG NETWORK DESIGN of FIBER TO THE BUILDING ( FTTB ) to SUPPORT SMART BUILING USING GPON IN GRAHA POS INDONESIA , BANDUNG," vol. 4, no. 2, pp. 558-564, 2018.

[8] A. Putra, A. Hambali, and B. Pamukti, "Perancangan Fiber To the Building ( Fttb ) Dengan Teknologi Berbasis Gpon Di Mall Cihampelas Walk Design of Fiber To the Building ( Fttb ) Network Using Gpon- Based Technology in Mall Cihampelas Walk," vol. 5, no. 2, pp. 2238-2246, 2018.

[9] T. N. Damayanti and H. Putri, "Performance Comparison of Transmission," J. Elektro Telekomun. Terap., pp. 356-368, 2016.

[10] A. M. J. Koonen, H. P. A. Van Den Boom, E. Tangdiongga, H. D. Jung, and P. Guignard, "Designing in-building optical fiber networks," Opt. InfoBase Conf. Pap., no. 1, pp. 1-3, 2010.

[11] A. J. Maulana, "Perencanaan Desain Jaringan Metro FTTH di Universitas Indonesia SKRIPSI Perencanaan Desain Jaringan Metro FTTH di Universitas Indonesia," Perenc. Desain Jar. Metro FTTH di Univ. Indones. SKRIPSI Perenc. Desain Jar. Metro FTTH di Univ. Indones., pp. 1-79, 2012.

[12] “ZTE ZXA10 C320 GPON OLT Specification." [Online]. Available: http://gponsolution.com/zte-zxa10-c320-gpon-oltspecification.html. [Accessed: 23-Nov-2019].

[13] "ORS 2/600 Optical Distribution Cabinet | Micos - website." [Online]. Available: https://www.micostelcom.com/ors-2-600optical-distribution-cabinet. [Accessed: 23-Nov-2019].

[14] "LW-ODB-24B Optical Distribution Point ODP Box - 24 Fibers." [Online]. Available: https://www.mylinkwell.com/portfolio-item/lw-odb-24boptical-distribution-point-odp-box/. [Accessed: 23-Nov-2019].

[15] "China 1/32 1/64 Plc SC/APC Splitter Equipment Manufacturers, Suppliers, Factory - Wholesale Cheap 1/32 1/64 Plc SC/APC Splitter Equipment - Tongmai." [Online]. Available: https://www.tmfibercable.com/ftth-accessories/1-32- 
1-64-plc-sc-apc-splitter-equipment.html. [Accessed: 23-Nov2019].

[16] “ZTE GPON.” [Online]. Available: http://www.ztegpon.com/index.php?page=660. [Accessed: 23 Nov-2019].

[17] G. A. Fibre, "Fibre specification G.657.A2," vol. 31, no. 0, p. 7481, 2018.

[18] “SFP-1G Series." [Online]. Available: http://www.manilaetech.com/product_SFP-1G.php\#specs. [Accessed: 23-Nov-2019].

[19] MICT, "Peraturan Menteri Komunikasi dan Informatika Nomor 3/Per/M/Kominfo/1/2007 tentang Sewa Jaringan,” 2007.

[20] Damayanti, Tri Nopiani dan Hasanah Putri. 2016. "Perbandingan Unjuk Kerja Transmisi Jaringan Fttb Menggunakan GEPON Dan GPON”. Bandung: Jurnal Elektro Telekomunikasi Terapan.

[21] A. H. Okeses Efriyanda, Delsina Faiza, "Analisis Kinerja Sistem Komunikasi Serat Optik Dengan Menggunakan Metode Power Link Budget Dan Rise Time Budget Pada Pt. Telkom,” vol. 10, no. April, pp. 36-53, 2015.

[22] G. Keiser, "Optical Fiber Communications" $3^{\text {rd }}$ Edition, pp 282 288. 2000. 